\title{
STRATEGIC MANAGEMENT INSTRUMENTS FOR CYBER-PHYSICAL ORGANIZATIONS: TECHNOLOGICAL POSTHUMANIZATION AS A DRIVER OF STRATEGIC INNOVATION
}

\author{
Matthew E. Gladden*
}

\begin{abstract}
Background. Strategic management instruments (SMIs) are tools used to analyze an organization's strategic situation, formulate effective strategies, and successfully implement them. Despite SMIs' importance, there has been little systematic research into them - and especially regarding the impact of emerging technologies on SMIs.

Research aims. Here we investigate whether the forces of technological posthumanization that are creating a new class of 'cyber-physical organizations' can be expected to affect innovation in the use of SMIs within such organizations.

Methodology. Through a review of strategic management literature, we identify nearly 100 SMIs and categorize them according to their use in (a) strategic analysis, (b) strategy formulation, or (c) strategy implementation. Meanwhile, an analysis of cyber-physical systems and technological posthumanization reveals three dynamics that are converging to create an emerging class of cyber-physical organizations: (a) roboticization of the workforce; (b) deepening human-computer integration; and (c) the ubiquitization of computation. A framework is developed for mapping the impacts of these dynamics onto the inputs, agents, processes, and outputs involved with the three types of SMIs.
\end{abstract}

Key findings. Application of the framework shows that technological posthumanization should be expected to both facilitate and require innovation in cyber-physical organizations' use of all three types of SMIs.

Keywords: Strategic Management Instruments, cyber-physical systems, cyber-physical organizations, roboticization, technological posthumanization.

* Institute of Computer Science, Polish Academy of Sciences. E-mail: matthew.e.gladden@ gmail.com 


\section{INTRODUCTION AND BACKGROUND}

\section{Defining the cyber-physical organization}

Over the last decade, the concept of the 'cyber-physical' entity has become well established, as researchers have formulated definitions for cyber-physical systems (Gill, 2008; Wang et al., 2008), cyber-physical-social systems (Liu et al., 2011; Smirnov et al., 2015), and cyber-physical societies (Zhuge, 2010; Monostori, 2014). Oblique references have also been made to the notion of a 'cyber-physical organization' (Liu et al., 2011; Byrnes, 2012; Drira in Reddy \& Reddy, 2016), without formally defining the term. By synthesizing such concepts, we can define a cyber-physical organization as "a heterogeneous collection of intelligent embodied agents that are united in the pursuit of a common goal and that form a network in which computational mechanisms for real-time communication and control are deeply embedded in the agents, their shared tools, and their workspace". We can consider these elements in more detail.

Heterogeneity of intelligent embodied agents. A cyber-physical organization differs from traditional enterprises in which natural biological human beings are the primary or only agents who gather and process information, make decisions, and act to advance an organization's goals. Within the cyber-physical organization, such workers are joined as intelligent embodied agents by a diverse array of synthetic entities such as social robots, smart vehicles, smart buildings, and other artificially intelligent systems, as well as by neurocybernetically enhanced human beings. In its heterogeneity, a cyber-physical organization resembles other types of cyber-physical entities (Gill, 2008; Wang et al., 2008; Smirnov et al., 2015).

Pursuit of a common goal. One of the defining traits of an organization is that it is "goal-directed" (Daft et al., 2010, p. 10). The fact that a cyber-physical organization's agents are united in the pursuit of a common goal is what makes their assemblage an organization rather than a more loosely connected society.

A deeply embedded computational network. A cyber-physical organization is not a collection of agents that operate in isolation from one another to achieve their shared purpose. Rather, such agents are functionally and cognitively integrated through their creation of 
a robust network in which biological, electronic, or hybrid computational mechanisms for real-time coordination and control are deeply embedded (Gill, 2008) in organizational resources. The cyber-physical organization does not simply 'utilize' one or more information systems; it becomes an information system that may comprise vast numbers of intelligent embodied agents.

\section{Emerging cyber-physical organizations}

Intensively cyber-physical organizations do not yet exist to be empirically studied; however, there are types of organizations that already display limited aspects of 'cyberphysicality' and whose further 'cyberphysicalization' is anticipated based on current trends. These include:

- Military organizations in which a pilot or soldier is integrated into a network of robotic devices through an augmented reality (AR) display, virtual reality (VR) system, or neuroprosthetic augmentation (Falconer, 2003; Gill, 2008).

- Cybersecurity organizations whose action is distributed across a global network of autonomous software agents, unified threat management (UTM) appliances, and human employees (Rao \& Nayak, 2014).

- Medical organizations whose facilities rely on robotic surgical devices, ubiquitous sensing for tracking of patients and equipment, robotic vehicles for deliveries throughout a facility, and neuroprostheses for the treatment of medical conditions (Gill, 2008; Datteri, 2013).

- 'Industry 4.0' manufacturing organizations that rely on robotic technologies for product assembly, testing, and distribution (Monostori, 2014; Perlberg, 2016).

- Retail and service organizations that utilize robotic staff to answer customers' queries and take and fulfill orders (Ford, 2015; Sachs et al., 2015).

- Virtual organizations in which human and artificial agents interact through a technologically mediated network (Shekhar, 2016),

- High-tech organizations employing implantable devices for employee tracking, monitoring, and access control (Clark, 2004; Koops \& Leenes, 2012; Brooks, 2017). 


\section{RESEARCH AIMS AND QUESTIONS}

Much research has been done regarding the ways in which growing cyberphysicalization will impact societies at a macroeconomic level - e.g., through the loss of human jobs to robots - and change the skill-sets needed for IT management within organizations (Ford, 2015; Sachs et al., 2015). However, almost no systematic research has been done regarding the ways in which cyberphysicalization will affect the methods and mechanisms by which individual organizations develop and implement competitive strategy.

The hypothesis of our research is that the unique dynamics found in cyber-physical organizations can be expected to enable the creation and use of new types of strategic management instruments (SMIs) that are not feasible for traditional organizations, thereby facilitating innovation in the development and application of SMIs; at the same time, some well-established SMIs may be expected to lose their effectiveness in cyber-physical organizations with highly novel architectures. This would mean that innovation in the sphere of SMIs is not simply an advantageous 'option' but rather a necessity for cyber-physical organizations.

\section{METHODOLOGY}

Our methodology involves three steps: (1) identifying the full spectrum of contemporary SMIs and classifying them into functional types based on their role in the strategic management process; (2) identifying key phenomena through which cyberphysicalization is manifested in cyber-physical organizations; and (3) mapping the expected impacts of those phenomena onto key elements of the different types of SMIs. Below these three steps are described in detail.

\section{Classifying contemporary SMIs into three types}

Considering its importance for the field of strategic management, surprisingly little research has been performed to systematically identify and compare strategic management instruments (Tassabehji \& Isherwood, 2014). Those undertaking such studies include Clark 
(1997); Woods and Joyce (2003); Lisiński and Šaruckij (2006); Vaitkevičius, Merkys, and Savanevičienè (2006); Stenfors and Tanner (2007); Vaitkevičius (2007); Afonina and Chalupský (2012); Erbaşı and Ünüvar (2012); and Tassabehji and Isherwood (2014). Together, these sources identify nearly one hundred tools and techniques that can be utilized as SMIs; these include such popular and diverse approaches as the SWOT and PESTEL analyses, Porter's Five Forces model, the Delphi method, budgeting, blue ocean strategy, and the balanced scorecard. Based on the phase of strategic management in which they are employed, it is possible to divide these SMIs into three groups: (a) SMIs for strategic analysis; (b) SMIs for strategy formulation; and (c) SMIs for strategy implementation. When the SMIs discussed in the cited literature are classified in this way, the groups contain 53, 16, and 28 SMIs, respectively, as shown in Figure 1.

\section{Analyzing three converging phenomena of technological posthumanization in cyber-physical organizations}

Through analysis of the concept of the cyber-physical organization and emerging examples of such organizations, we can identify three dynamics that converge within such organizations: (a) the roboticization of organizational agency and action; (b) human-computer integration and the 'cyborgization' of the human workforce; and (c) the ubiquitization and non-localization of computation. Collectively, these phenomena reflect the dynamic of 'technological posthumanization' by which society comes to include many different types of intelligent social actors - beyond just natural biological human beings - who seek to perceive, interpret, and influence their shared environment and who create knowledge and meaning through their networks and interactions (Gladden, 2016; Herbrechter, 2013). We can consider these dynamics in more detail.

Roboticization of organizational agency and action. Within cyber-physical organizations, a growing range of tasks that were previously handled by human employees are assigned to embodied artificial agents (or robots), thereby creating a more heterogeneous human-synthetic network of computational systems (Ford, 2015; Sachs et al., 2015). This roboticization is further expanded by the fact that computers can be embedded in previously passive organizational tools (such as vehicles or buildings), turning them 


\section{SMIs for Strategic Analysis (53)}

Activity-based costing ( $A B C)$

Analytical customer relationship management

Benchmarking

Blue sky thinking

Brainstorming

Brand equity analysis

Comb analysis

Competitor analysis

Conjoint analysis

Cost-benefit analysis

The cultural web

The Delphi method

Dialectical inquiry

Economic forecasting

Experience curve analysis

External Factor Evaluation (EFE) Matrix

Financial forecasting

Financial statement analysis

Focus groups

Futures studies

The Hofer matrix

Industry life cycle analysis

Internal Factor Evaluation (IFE) Matrix

Market opportunity analysis

Market segmentation

Market share analysis

Market signal analysis

Net promoter score

New-product diffusion analysis

PESTEL analysis (and variants)

Porter's Diamond model

Porter's Five Forces model

Price analysis

Product life cycle analysis

Product Portfolio Matrix (BCG Matrix)

Profit Impact of Marketing Strategy (PIMS)

QUEST analysis

Relative probability analysis

Resource analysis

Risk analysis

SPIRE environmental forecasting

Spreadsheet modeling

Stakeholder analysis

Statistical analyses

Strategic gap analysis

Strategic group analysis

Surveys

SWOT analysis

Technology assessment

Trend analysis

Value chain analysis

Vulnerability analysis

Win/loss analysis
SMIs for Strategy Formulation (16)

The Ansoff Matrix

ASTRA analysis

Blue ocean strategy

Bowman's Strategy Clock

Budgeting

Game theory

The GE-McKinsey Matrix

Market mapping (perceptual maps)

Mission and vision statements

Nominal group technique

Scenario planning

Search conference

Simulations

SPACE analysis

Strategic balance

Strategic planning

\section{SMIs for Strategy Implementation (28)}

Analysis of advertising effectiveness

Balanced scorecard

Business process mapping

Core competencies

Critical success factors

Downsizing

Employee attitude analysis

Enterprise resource planning (ERP)

Hoshin Kanri

HR management tools

The learning organization

Management information systems

McKinsey 75

Online commerce

Open book management

Operational customer relationship management

Optimization methods

Organization development

Organizational structures

Outsourcing

Performance reviews

Project management tools

Quality circles

Quality management

Reengineering

Regular monitoring

Strategic TQM

Supply chain management

Figure 1. A classification of popular strategic management instruments based on their use in the strategic management phases of strategic analysis, strategy formulation, or strategy implementation.

Source: own synthesis and classification of SMIs identified in reviews by Clark (1997), Woods and Joyce (2003), Lisiński and Šaruckij (2006), Vaitkevičius et al. (2006), Stenfors and Tanner (2007), Vaitkevičius (2007), Afonina and Chalupský (2012), Erbaşı and Ünüvar (2012), and Tassabehji and Isherwood (2014). 
into networked robotic agents and loci for real-time processes of communication and control.

Human-computer integration and the 'cyborgization' of the human workforce. Through the use of implanted, wearable, or mobile devices, the physical person of a human worker becomes a locus for electronic computational processes of real-time organizational communication and control (Fleischmann, 2009; Koops \& Leenes, 2012; Gladden, 2016). Through such ICT, a human worker becomes and remains integrated into an organization's network of electronic information systems in ways that were previously impossible.

In some cases, the widespread cyberization of the human workforce is already giving way to a more invasive process of 'cyborgization' by which human workers do not simply possess intimate relationships with exterior pieces of organizational ICT but incorporate such technologies into their bodies' biological structures and processes through neuroprosthetic augmentation (Clark, 2004; Fleischmann, 2009; Koops \& Leenes, 2012; Gladden, 2017). Military organizations are largely driving the development of such neurocybernetically augmented organizational forms (Falconer, 2003).

Ubiquitization and non-localization of computation. Thanks to advances in the development of inexpensive nanodevices and the management of robotic swarms and the Internet of Things, it is increasingly feasible for an organization to infuse its physical environment with thousands (or even millions) of robotic agents who visibly or invisibly fill the space between their human collaborators and extend the organization's reach of sensation, cognition, and action beyond the walls of its facilities and throughout the broader digital-physical ecosystem (Berner, 2004; Poslad, 2011; Evans, 2012; Barca \& Sekercioglu, 2013). Within such complex networked systems, computation for purposes of communication and control can become ubiquitous within an organization's physical resources and agency and decision-making may be emergent and non-localizable to a particular point within the environment (Greenfield, 2010; Poslad, 2011). 


\section{Mapping expected impacts of cyberphysicalization to elements of SMIs}

The use of a strategic management instrument involves four elements: (a) the inputs or raw materials upon which the SMI acts; (b) the agent who executes the SMI; (c) the process by which the SMI is carried out; and (d) the outputs generated by the SMI. Since there are three types of SMIs (for analysis, formulation, and implementation) and each type possesses all four elements, there are many locations in the process of strategic management where the dynamics of cyberphysicalization can enable or require innovation in SMIs. This is reflected in Figure 2.
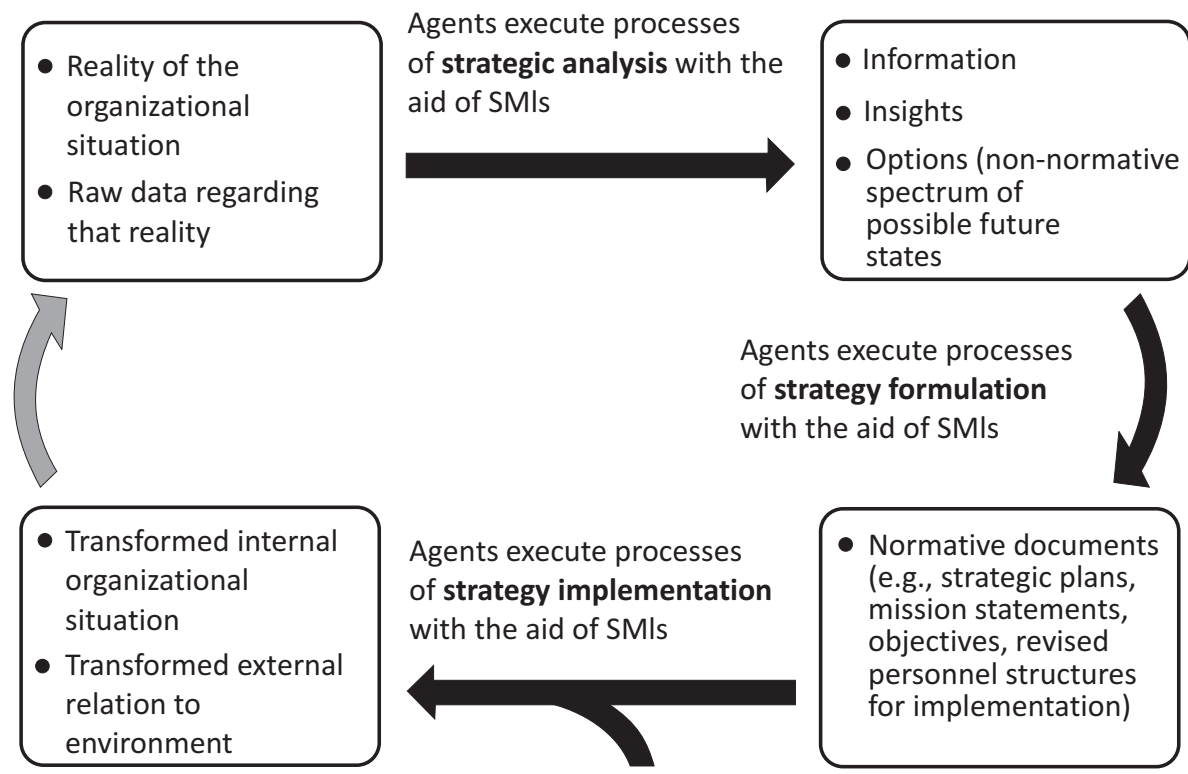

Agents execute processes of strategy formulation with the aid of SMls

Agents execute processes of strategy implementation with the aid of SMls

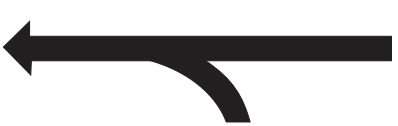

- Reality of the organizational situation

Figure 2. Different types of SMIs are used in strategic analysis, strategy formulation, and strategy implementation, and each type involves (a) inputs, (b) an agent, (c) a process, and (d) outputs; this creates many possible sites for innovation. 
Through a review of the literature cited above, we identified a wide range of ways in which researchers investigating the impacts of roboticization, human-computer integration, and the ubiquitization of computation expect such dynamics to affect what we refer to as 'cyber-physical organizations' or 'CPOs'. By analyzing the relationship of such dynamics to the inputs, agents, processes, and outputs of the three types of SMIs, we were able to 'map' the impacts of cyberphysicalization onto the space for innovation in SMIs and identify ways in which cyberphysicalization can be expected to both facilitate and demand innovation in SMIs.

\section{FINDINGS}

Below we summarize ways in which the effects of roboticization, human-computer integration, and the ubiquitization of computing that have been identified by researchers can be expected to simultaneously enable and require innovation in the development and application of SMIs in all three stages of strategic management.

\section{Impacts of roboticization}

On SMIs for strategic analysis. Robotic agents can gather and analyze certain types of data faster, more accurately, and with greater consistency than human agents; the variety of sensors available for robots means that such agents may also be able to collect data that is not directly accessible to natural biological human beings at all (Berner, 2004; Ford, 2015; Perlberg, 2016). Moreover, the replacement of varied and unpredictable human workers with more uniform and predictable robotic agents may make it easier to represent and analyze an organization's internal structure and dynamics.

On the other hand, the loss of human workers may make it harder for a roboticized organization to gather data (e.g., information about customer attitudes acquired through social interactions with customers) that is needed as input for some SMIs and which human workers easily absorb but which robotic systems may struggle to acquire.

On SMIs for strategy formulation. A workforce whose human workers have largely been replaced by robotic agents (Ford, 2015; Sachs et al., 2015 ) will include a reduced number of human employees who must be 
engaged by those SMIs for which stakeholder participation is important, thereby streamlining such SMIs' use. SMIs may also be able to consider a broader range of strategic options, as some previously deemed too radical become less risky to adopt. For example, a strategy that involves eliminating half of an organization's workforce may become more practical if that workforce is already composed primarily of robotic agents for whom impacts on morale are not a concern. Strategies that were once impossible may even become feasible: for example, it may be possible to adopt a strategy that requires an organization's robotic workforce to dramatically alter the nature of its work - and acquire an entirely new set of skills - several times a day, in order to adapt to shifting market opportunities. Such instant retraining might be accomplished simply by uploading a file with new skill-sets into the robotic system's controller or downloading such information into individual robotic agents. Just as contemporary cloud service providers create a flexible and scalable computing platform that can be instantly retooled by clients to perform new tasks, a robotic workforce may be capable of instantaneous strategic transformation and redeployment; such possibilities can be expected to facilitate the development of new SMIs for strategy formulation that can take advantage of their potential.

At the same time, an organization that has made a costly long-term investment in the roboticization of its workforce may be unwilling to consider adopting strategies that would render it obsolete; roboticization may thus limit the range of strategic options that SMIs are allowed to formulate. Moreover, while AI's ability to generate creative ideas and solutions to problems is advancing rapidly (Berner, 2004; Ford, 2015), a roboticized workforce will have fewer human personnel who can produce creative strategic options for consideration via SMIs. Existing artificial agents are also not effective at generating normative documents such as mission statements or strategic plans; a highly roboticized organization may thus not possess the internal human resources needed to employ traditional SMIs used for generating such outputs.

On SMIs for strategy implementation. The fact that existing types of robots do not sabotage organizational change in the way that disappointed human workers sometimes do means that SMIs for strategy implementation in roboticized organizations do not need to dedicate attention to addressing such phenomena. Moreover, instead of requiring months of retraining and evaluation, SMIs for radically transforming an organization's architecture might simply involve 
installing a new plugin for robotic management software or altering a few application settings (Perlberg, 2016; Ford, 2015). It may be possible to continually adjust such strategies through real-time control or reprogramming of robotic agents.

On the other hand, adjusting some robotic systems to execute what new strategies demand of them may be difficult, due to rigidities in the robots' physical structure or data-processing mechanisms (Perlberg, 2016); even the most flexible robots currently lack the adaptability of human workers who - despite whatever specialized expertise they possess - are ultimately 'generalists' who can be trained, motivated, and deployed to perform a wide range of tasks. SMIs that presume a workforce to possess creative problem-solving ability may also falter when applied to a robotic workforce that does not proactively look for imaginative ways of implementing strategies.

\section{Impacts of human-computer integration}

On SMIs for strategic analysis. Cyborgization can provide human agents with new capacities for gathering data about themselves and their environment; visualizing, analyzing, and interpreting the data; and sharing information with others (Clark, 2004; Koops \& Leenes, 2012; Gladden, 2017). Such capacities may enable human actors to utilize SMIs for strategic analysis with previously impossible speed, scope, and accuracy.

At the same time, neurocybernetic augmentation has the potential to dramatically increase the data received by a human worker's sense organs or brain. This may produce information overload that increases the duration and complexity of analytical processes, and traditional SMIs premised on the analysis of all available information may become impractical if that 'all available information' has become overwhelming in quantity and unlimited in scope.

On SMIs for strategy formulation. It may be possible to link neuroprosthetically augmented human workers (and perhaps also AIs) to form a 'hive mind' whose members share sensations, emotions, and imaginings and generate collective decisions and actions (McIntosh, 2010; Gladden 2017). Future SMIs could potentially allow strategy to be formulated almost instantaneously through such intimate interplay and sharing of ideas and sentiments among a large number of minds.

On the other hand, an organization's human workforce may become so closely integrated with its electronic information systems (Fleischmann, 
2009; Liu et al., 2011) that it is impossible to dramatically transform one without significantly altering (and perhaps negatively impacting) the other. Traditional types of SMIs for strategy formulation that consider an organization's workforce in isolation from its electronic information systems may no longer be effective or appropriate; new SMIs may need to be developed that display a better understanding of the nature of human-computer integration.

On SMIs for strategy implementation. Members of a neuroprosthetically augmented human workforce may be able to receive continuous instructions regarding strategy implementation channeled directly into their sense organs or brains; they may also be able to engage in real-time sharing of data about successes and failures of operational efforts to implement strategies (Koops \& Leenes, 2012; Gladden, 2017). Such capacities may enable the development of SMIs for strategy implementation that can be adjusted in real time and which counteract limitations that prevent natural biological human workers from effectively implementing new strategies.

At the same time, the use of AR or VR technologies may create distractions for human workers that divide their attention between the 'real' and 'virtual' worlds in a manner that impairs their ability to implement organizational strategies. Cyber-physical organizations may also require new types of SMIs that robustly manage the distinction between those competitive battles fought in the primary physical world of material goods and geographical locations and those fought entirely within virtual realms (Zhuge, 2010; Shekhar, 2016): while the latter might involve transformations that are obvious to such environments' inhabitants (such as alteration of the laws of physics that apply within persistent virtual worlds), the 'real-world' manifestation of such changes may be little more than altered values of bytes on a server's hard drive. Finally, a workforce's deep integration with organizational information systems means that traditional SMIs used for strategy implementation may become ineffective or inoperable during system outages or in areas of real or virtual space that cannot easily be manipulated via such systems.

\section{Impacts of the ubiquitization of computing}

On SMIs for strategic analysis. The pervasive presence of networked sensors throughout the organizational workspace - and potentially throughout the broader external environment - can dramatically 
increase the quantity and variety of real-time data available to SMIs for strategic analysis (Poslad, 2011; Evans, 2012). Within such a context, any point in the internal or external environment can become a networked locus for real-time data-gathering; this may enable the development of new types of SMIs for strategic analysis that were previously impractical or impossible.

On the other hand, the exponential increases in the quantity of raw data available for analysis that result from ubiquitous computing render traditional analytical techniques ineffective and may require the development of new SMIs grounded in Big Data approaches.

On SMIs for strategy formulation. The networking of ubiquitous ICT devices may allow all of an organization's computational agents to weigh in on potential strategies in real time as they are being formulated. This would allow the participation in strategy-making not only of human workers but of all non-human organizational resources that are incorporated into the ecosystem of the organization's information systems.

However, the ubiquitization of computing can simultaneously result in a fragmentation of computation among a vast network of heterogeneous agents, which complicates the use of traditional SMIs that seek to engage all stakeholders and generate consensus strategies.

On SMIs for strategy implementation. A digital-physical ecosystem that is suffused with vast numbers of networked ubiquitous devices - such as those found in a nanorobotic swarm (Greenfield, 2010; Barca \& Sekercioglu, 2013) - might offer a cyber-physical organization millions of effectors that can be used to manipulate its internal or external environment at the microscopic or macroscopic levels. New types of SMIs may allow an organization to implement strategies with unprecedented speed, scope, and precision through such direct stimulation or manipulation of the organization's human and robotic workforce, internal resources, and external environment. The ethical issues involved with such possibilities are highly complex.

While the ubiquitization of computing may create vast quantities of new effectors by which an organization can manipulate its internal or external environment, that is not necessarily a beneficial development: in such a situation, strategy implementation may no longer involve the successful management of hundreds or thousands of human workers but of millions of semi-autonomous heterogeneous networked agents. 


\section{DISCUSSION AND CONCLUSIONS}

Our analysis suggests that for each of the three phases of strategic management, the convergent dynamics of technological posthumanization that are manifested by cyber-physical organizations should be expected to facilitate the development of cheaper, faster, simpler, and more powerful strategic management instruments while simultaneously rendering other types of existing SMIs more expensive, more time-consuming, or otherwise less effective. These dual impacts will require the nascent class of cyber-physical organizations to adopt innovative SMIs that are suitable to the unique context in which they are being employed. It is hoped that the analysis presented in this text has contributed to delineating the landscape for future empirical research within this emerging subdomain of strategic management.

\section{REFERENCES}

Afonina, A. \& Chalupský, V. (2012). The current strategic management tools and techniques: The evidence from Czech Republic. Economics and Management, 17(4), 1535-1544.

Barca, J.C. \& Sekercioglu, Y.A. (2013). Swarm robotics reviewed. Robotica, 31(3), $345-359$.

Berner, G. (2004). Management in 20XX: What Will Be Important in the FutureA Holistic View. Erlangen: Publicis Corporate Publishing.

Brooks, J. (2017). Swedish workers implanted with microchips to replace cash cards and ID passes. The Independent, April 6, 2017. http://www.independent. co.uk/news/world/europe/sweden-workers-microchip-implant-cash-cardid-pass-replace-employee-hand-epicenter-rice-grain-size-a7670551.html (access: 25.04.2017).

Byrnes, J.T. (2012). Milwaukee Institute presentation. Milwaukee Chapter, Wisconsin Innovation Network. Crowne Plaza Hotel. May 10, 2012.

Clark, A. (2004). Natural-born Cyborgs: Minds, Technologies, and the Future of Human Intelligence. Oxford: Oxford University Press.

Clark, D.N. (1997). Strategic management tool usage: A comparative study. Strategic Change, 6(7), 417-427.

Daft, R.L., Murphy, J. \& Willmott, H. (2010). Organization Theory and Design. Andover, Hampshire: Cengage Learning EMEA. 
Datteri, E. (2013). Predicting the long-term effects of human-robot interaction: A reflection on responsibility in medical robotics. Science and Engineering Ethics, 19(1), 139-160.

Erbaşı, A. \& Ünüvar, Ş. (2012). The levels of using strategic management tools and satisfaction with them: A case of five-star hotels in Turkey. International Journal of Business and Management, 7(20), 71.

Evans, D. (2012). The Internet of everything: How more relevant and valuable connections will change the world. Cisco Internet Solutions Business Group: Point of View. https://www.cisco.com/web/about/ac79/docs/innov/IoE.pdf (access: 16.12.2015).

Falconer, B. (2003). Defense research agency seeks to create supersoldiers. Government Executive. November 10, http://www.govexec.com/defense/2003/11/ defense-research-agency-seeks-to-create-supersoldiers/15386/ (access: 22.05.2016).

Fleischmann, K.R. (2009). Sociotechnical interaction and cyborg-cyborg interaction: Transforming the scale and convergence of HCI. The Information Society, 25(4), 227-235.

Ford, M. (2015). Rise of the Robots: Technology and the Threat of a Jobless Future. New York: Basic Books.

Gill, H. (2008). From vision to reality: Cyber-physical systems. In: HCSS National Workshop on New Research Directions for High Confidence Transportation CPS: Automotive, Aviation, and Rail. Vienna.

Gladden, M.E. (2016). Sapient Circuits and Digitalized Flesh: The Organization as Locus of Technological Posthumanization. Indianapolis: Defragmenter Media.

Gladden, M.E. (2017). Neuroprosthetic Supersystems Architecture: Considerations for the Design and Management of Neurocybernetically Augmented Organizations. Indianapolis: Synthypnion Academic.

Greenfield, A. (2010). Everyware: The Dawning Age of Ubiquitous Computing. New Riders.

Herbrechter, S. (2013). Posthumanism: A Critical Analysis. London: Bloomsbury. [Kindle edition.]

Koops, B.-J. \& Leenes, R. (2012). Cheating with implants: Implications of the hidden information advantage of bionic ears and eyes. In: M.N. Gasson, E. Kosta \& D.M. Bowman (eds.), Human ICT Implants: Technical, Legal and Ethical Considerations. T.M.C. Asser Press, 113-134.

Lisiński, M. \& Šaruckij, M. (2006). Principles of the application of strategic planning methods. Journal of Business Economics and Management, 7(2), 37-43.

Liu, Z., Yang, D., Wen, D., Zhang, W. \& Mao W. (2011). Cyber-physical-social systems for command and control. IEEE Intelligent Systems, 26(4), 92-96. 
McIntosh, D. (2010). The transhuman security dilemma. Journal of Evolution and Technology, 21(2), 32-48.

Monostori, L. (2014). Cyber-physical production systems: Roots, expectations and R\&D challenges. Procedia CIRP, 17, 9-13.

Perlberg, J. (2016). Industrial Robotics. Boston: Cengage Learning.

Poslad, S. (2011). Ubiquitous Computing: Smart Devices, Environments and Interactions. Chichester: John Wiley \& Sons.

Rao, U.H. \& Nayak, U. (2014). The InfoSec Handbook. New York: Apress.

Reddy, S.M. \& Reddy, Y.V. (2016). WETICE Conference: The First 25 Years. In: Enabling Technologies: Infrastructure for Collaborative Enterprises (WETICE), 2016 IEEE 25th International Conference on, xiv-xvii. IEEE.

Sachs, J.D., Benzell, S.G. \& LaGarda, G. (2015). Robots: Curse or Blessing? A Basic Framework. NBER Working Papers Series, Working Paper 21091. Cambridge, MA: National Bureau of Economic Research.

Shekhar, S. (2016). Managing the Reality of Virtual Organizations. Chennai: Springer India.

Smirnov, A., Kashevnik, A. \& Ponomarev, A. (2015). Multi-level self-organization in cyber-physical-social systems: Smart home cleaning scenario. Procedia CIRP, 30, 329-334.

Stenfors, S. \& Tanner, L. (2007). Evaluating strategy tools through activity lens. Helsinki School of Economics Working Papers, W-419. Helsinki: Helsinki School of Economics.

Tassabehji, R. \& Isherwood, A. (2014). Management use of strategic tools for innovating during turbulent times. Strategic Change, 23(1-2), 63-80.

Vaitkevičius, S. (2007). Application of strategic management tools in Lithuania: Managers' knowledge and experience. Engineering Economics, 4(54), 70-77.

Vaitkevičius, S., Merkys, G. \& Savanevičienè, A. (2006). Model of Strategic Analysis Tools Typology. Engineering Economics, 2(47), 99-109.

Wang, Y., Vuran, M.C. \& Goddard, S. (2008). Cyber-physical systems in industrial process control. ACM Sigbed Review, 5(1), 12.

Woods, A. \& Joyce, P. (2003). Owner-Managers and the practice of strategic management. International Small Business Journal, 21(2), 181-195.

Zhuge, H. (2010). Cyber physical society. In: Proceedings of the 2010 Sixth International Conference on Semantics, Knowledge and Grids. IEEE Computer Society, 1-8. 


\title{
NARZĘDZIA ZARZĄDZANIA STRATEGICZNEGO DLA ORGANIZACJI CYBER-FIZYCZNYCH: TECHNOLOGICZNA POSTHUMANIZACJA JAKO BODZIEC DLA INNOWACJI STRATEGICZNEJ
}

\begin{abstract}
Abstrakt
Tło badań. Narzędzia zarządzania strategicznego (SMIs) są instrumentami używanymi w analizie sytuacji strategicznej organizacji oraz $\mathrm{w}$ formułowaniu i realizacji skutecznych strategii. Pomimo że SMIs są dość ważne, mało jest systematycznych badań poświęconych im i wpływowi nowo powstających technologii na nie.
\end{abstract}

Cel badań. Analiza dotyczy pytania, czy można się spodziewać, że siły technologicznej posthumanizacji tworzące nową klasę „organizacji cyberfizycznych” będą miały wpływ na innowacje w użyciu SMIs w takich organizacjach.

Metodologia. Analizując literaturę o zarządzaniu strategicznym, identyfikujemy prawie 100 SMIs i kategoryzujemy je według ich użycia w: (a) analizie strategicznej, (b) formułowaniu strategii oraz (c) realizacji strategii. Tymczasem analiza systemów cyberfizycznych i technologicznej posthumanizacji pokazuje trzy trendy, które zbiegaja się, aby tworzyć rozwijająca się klasę organizacji cyberfizycznych: (a) robotyzacja siły roboczej; (b) pogłębienie integracji ludzko-komputerowej; oraz (c) ubikwityzacja obliczenia. Artykuł proponuje pojęciową strukturę dla odwzorowania wpływów wymienionych trendów na wkład, agentów, procesy i produkty związane z trzema typami SMIs.

Kluczowe wnioski. Zastosowanie zaproponowanej struktury pojęciowej sugeruje, że można się spodziewać, iż technologiczna posthumanizacja będzie i ułatwiać innowacyjność, i wymagać jej w użyciu przez organizacje wszystkich trzech rodzajów SMIs.

Słowa kluczowe: narzędzia zarządzania strategicznego, systemy cyberfizyczne, organizacje cyberfizyczne, robotyzacja, technologiczna posthumanizacja. 